\title{
PENYULUHAN TERTIB BERLALU LINTAS PADA KALANGAN REMAJA OLEH SATLANTAS POLRES KLATEN
}

\author{
Sri Herwindya Baskara Wijaya ${ }^{1}$, Mahfud Anshori' ${ }^{1}$, Dwi Tiyanto ${ }^{1}$, Aryanto Budhy \\ Sulihyantoro', Deniawan Tommy Candra Wijaya $^{1}$, Ina Primasari, \\ Henricus Hans Setyawan Prabowo1, Eka Nada Shofa Alkhajar ${ }^{2}$ \\ ${ }^{1}$ Sekolah Vokasi Universitas Sebelas Maret Surakarta \\ ${ }^{2}$ Fakultas Ilmu Sosial dan Ilmu Politik Universitas Sebelas Maret Surakarta
}

\begin{abstract}
herwindya82@gmail.com,mahfudanshori_fisip@staff.uns.ac.id, dwitiyanto@staff.uns.ac.id, aryanto.budhy@ staff.uns.ac.id, deniawantommy@staff.uns.ac.id, inaprimasari@staff.uns.ac.id, henricushans@yahoo.com, ekanadashofa@staff.uns.ac.id
\end{abstract}

\begin{abstract}
Abstrak
Tertib berlalu lintas adalah hal utama bagi semua pengendara atau pengguna jalan terutama di jalan raya. Namun, belum semua pengguna jalan raya mau untuk tertib berlalu lintas. Bukan hanya melanggar aturan yang berlaku seperti tidak membawa surat-surat berkendara dan melanggar rambu-rambu lalu lintas, namun juga mengakibatkan kecelakaan dengan korban luka hingga meninggal dunia. Terkait dengan permasalahan itulah maka digelar kegiatan pengabdian kepada masyarakat berupa penyuluhan tertib berlalu lintas dalam rangka meningkatkan kesadaran berkendara di masyarakat. Penyuluhan ini diselenggarakan pada Rabu, 26 Agustus 2020 bertempat di Balai Desa Taji, Juwiring, Klaten. Peserta berjumlah sekitar 50-an orang terutama dari kalangan remaja dengan materi utama mengenai tertib berlalu lintas. Pemateri berasal dari Satlantas Polres Klaten dan tim dosen Universitas Sebelas Maret (UNS) Surakarta. Kegiatan ini dilaksanakan dengan empat metode utama penyampaian materi, yakni presentasi video, ceramah, diskusi dan praktik di lapangan. Dampak dari kegiatan ini adalah meningkatnya wawasan peserta tentang tertib berlalu lintas sehingga meningkat pula kesadaran untuk berkendara dengan baik dan benar di jalan raya.
\end{abstract}

Kata Kunci: tertib lalu lintas, pengguna jalan, pelanggaran, penyuluhan, remaja

\section{PENDAHULUAN}

Di era modern ini, mobilitas yang dinamis merupakan salah satu aspek penting dalam kehidupan. Tak heran, transportasi pun menjadi hal yang sangat penting untuk mendukung akselerasi mobilitas tersebut. Terlebih lagi jumlah penduduk dunia setiap tahun terus bertambah yang diiringi dengan peningkatan kuantitas kendaraan bermotor baik pribadi maupun kendaraan umum. Jumlahnya terus bertambah baik itu kendaraan roda dua, roda empat atau lebih. Tak pelak, kondisi lalu lintas di jalan raya juga semakin padat dan sesak akibat dijejali banyak kendaraan utamanya kendaraan pribadi.

Salah satu pengguna jalan raya yang belakangan ini kian banyak menjamur di Indonesia berasal dari kalangan remaja. Banyak remaja yang telah mengendarai kendaraan bermotor baik roda dua maupun roda empat di jalan raya. Namun, ada sesuatu yang memprihatinkan di mana sebagian dari mereka belum memiliki kompetensi berkendara yang baik. Bahkan, banyak dari mereka yang belum

$$
\text { Teknologi Informasi dan Komunikasi }
$$


memiliki Surat Izin Mengemudi (SIM) lantaran usia mereka yang belum genap 17 tahun.

Kondisi itu masih disertai dengan sejumlah pelanggaran berlalu lintas lain seperti mengemudi dengan kecepatan tinggi atau sangat tinggi (mengebut), tidak mengenakan helm, tidak membawa Surat Tanda Nomor Kendaraan (STNK), spion tidak ada atau tidak lengkap, knalpot dibuat nyaring suaranya, berboncengan tiga orang atau lebih dan lain-lain. Tentunya semua ini menjadi keprihatinan dan permasalahan tersendiri bagi masyarakat secara luas khususnya para pengendara yang lain.

Para remaja ini jelas perlu disadarkan. Salah satunya adalah melalui pendidikan atau penyuluhan tertib berlalu lintas agar mereka sadar dan tidak menganggap pelanggaran berlalu lintas yang mereka lakukan sebagai sesuatu yang biasa atau wajar adanya. Padahal hal tersebut tak lain adalah tindakan yang keliru. Seperti diketahui, fase remaja merupakan masa transisi dari kehidupan anak-anak menuju dewasa sehingga mereka memerlukan bimbingan, pembinaan dan pendidikan yang tepat (Alkhajar, 2007; Sarwono, 2011; Alkhajar, 2014).

Sementara itu, di dalam Undang-Undang Nomor 22 Tahun 2009 tentang Lalu lintas dan Angkutan Jalan (selanjutnya disebut UU LLAJ) pun telah dinyatakan bahwa setiap orang yang mengemudikan kendaraan bermotor di jalan wajib mengemudikan kendaraannya dengan wajar dan penuh konsentrasi, mengutamakan keselamatan pejalan kaki dan pesepeda, mematuhi ketentuan tentang persyaratan teknis dan laik jalan, mematuhi ketentuan rambu perintah atau rambu larangan, marka jalan, alat pemberi isyarat lalu lintas, gerakan lalu lintas, berhenti dan parkir, peringatan dengan bunyi dan sinar, kecepatan maksimal atau minimal, dan/atau, tata cara penggandengan dan penempelan dengan kendaraan lain.

Di samping itu, regulasi terkait juga menyatakan bahwa pada saat diadakan pemeriksaan kendaraan bermotor di jalan setiap orang yang mengemudikan kendaraan bermotor roda dua, empat atau lebih wajib menunjukkan Surat Tanda Nomor Kendaraan (STNK), Surat Izin Mengemudi (SIM), bukti lulus uji berkala dan/atau tanda bukti lain yang sah. Bagi kendaraan roda empat atau lebih, penumpang yang duduk di samping pengendara wajib mengenakan sabuk keselamatan.
Khusus bagi pengendara sepeda motor wajib mengenakan helm yang memenuhi Standar Nasional Indonesia (SNI), dan sepeda motor tanpa kereta samping dilarang membawa penumpang lebih dari 1 (satu) orang.

Di antara akibat fatal dari perilaku tidak tertib berlalu lintas adalah terjadinya kecelakaan lalu lintas baik kecelakaan tunggal maupun nontunggal dengan korban luka-luka ringan, sedang, berat bahkan hingga meninggal dunia. Kondisi ini semakin rumit dan memprihatinkan ketika pengendara yang mengalami kecelakaan itu tidak memiliki kelengkapan surat-surat berkendara terutama SIM dan STNK.

Kecelakaan terkait tidak hanya melibatkan sesama pengendara, namun kadang juga mengakibatkan korban pengguna jalan lain seperti pejalan kaki atau bahkan masyarakat yang rumahnya berada di tepi jalan. Selain belum kompeten untuk berkendara, kecelakaan ini juga terjadi lantaran kondisi fisik kendaraan yang tidak memenuhi standar resmi seperti helm tidak standar atau bahkan tidak mengenakan helm, lampu utama atau lampu sein mati, tidak ada atau tidak lengkap spion hingga rem gas mati.

Berdasarkan data Polri, secara total terdapat 107.500 peristiwa kecelakaan lalu lintas pada 2019. Angka ini meningkat dari 103.672 peristiwa pada 2018. Sementara itu, jumlah korban meninggal dunia akibat kecelakaan lalu lintas pada 2019 berjumlah 23.530 orang. Angka ini turun dari 27.910 korban jiwa pada 2018. Adapun jumlah pelanggaran lalu lintas selama 2019 meningkat dari tahun 2018 yakni 7.456 .913 pelanggaran tilang dan 3.620.393 pelanggaran berbuah teguran (Ramadhan, 2019).

Lalu lintas sendiri di dalam UU LLAJ didefinisikan sebagai gerak kendaraan dan orang di ruang lalu lintas jalan. Pengaturan tentang lalu lintas dan angkutan jalan secara nasional diatur dalam UU LLAJ tersebut. Undang-Undang ini pun menjadi dasar dan pedoman dalam pengembangan, rekayasa serta penindakan terhadap pelanggaran lalu lintas. Ketentuan mengenai pidana terhadap pengemudi dalam kecelakaan lalu lintas secara jelas telah diatur dalam UU LLAJ. Dengan berlakunya undangundang tersebut, masyarakat diharapkan dapat mematuhi dan menaati keseluruhan aturan hukum tentang berkendara atau berlalu lintas di Indonesia, sehingga dapat tercipta keselamatan, keamanan dan 
kelancaran lalu lintas serta meningkatkan kesejahteraan masyarakat seiring dengan kemajuan ilmu pengetahuan dan teknologi.

Pelanggaran terhadap ketentuan pidana tentang lalu lintas dapat menyebabkan terjadinya kecelakaan lalu lintas yang menimbulkan kerugian baik sendiri maupun orang lain. Kecelakaan yang ditimbulkan tersebut bukan hanya tabrakan antar sesama kendaraan bermotor tetapi juga dengan pengguna atau pemakai jalan lainnya. Dalam kecelakaan semacam itu, pada umumnya orang akan mempermasalahkan mengenai hukuman yang dijatuhkan kepada si pelaku yang bersalah dalam kecelakaan tersebut. Akibat hukum terjadinya kecelakaan lalu lintas menimbulkan adanya tuntutan pidana terhadap pelaku tindak pidana kecelakaan lalu lintas. Pengaturan hukum mengenai kecelakaan lalu lintas itu sendiri telah diatur dalam berbagai peraturan perundang-undangan baik itu Kitab Undang-Undang Hukum Pidana (KUHP) maupun UU LLAJ (Prasetya, 2016: 24).

Kecelakaan lalu lintas menurut Pasal 1 ayat (24) UU LLAJ didefinisikan sebagai suatu peristiwa di jalan yang tidak diduga dan tidak disengaja melibatkan kendaraan dengan atau tanpa pengguna jalan lain yang mengakibatkan korban manusia dan/atau kerugian harta benda. Macam-macam kecelakaan lalu lintas menurut UU tersebut antara lain: (a) Kecelakaan lalu lintas ringan merupakan kecelakaan yang mengakibatkan kerusakan kendaraan dan/atau barang, (b) Kecelakaan lalu lintas sedang merupakan kecelakaan yang mengakibatkan luka ringan dan kerusakan kendaraan dan/atau barang, (c) Kecelakaan lalu lintas berat merupakan kecelakaan yang mengakibatkan korban meninggal dunia atau luka berat.

Untuk menghindari terjadinya kecelakaan dan pelanggaran lalu lintas lainnya, maka diperlukan adanya kesadaran hukum. Soerjono Soekanto mengatakan bahwa "untuk mengetahui tingkat kesadaran hukum masyarakat terdapat empat indikator yang dijadikan tolak ukur yaitu pengetahuan hukum, pemahaman hukum, sikap hukum dan pola perilaku hukum." Setiap indikator tersebut menunjukkan tingkat kesadaran hukum tertentu mulai dari yang terendah sampai dengan tertinggi (Soekanto, 2000, dalam Rahawarin, 2016: 135). Salah satu parameter kesadaran hukum adalah tindakan disiplin mematuhi tata tertib lalu lintas dalam berkendara.

Lemahnya kesadaran masyarakat terhadap peraturan berlalu lintas terlihat dari rendahnya tingkat kedisiplinan masyarakat dalam berkendara, sehingga melahirkan budaya tidak disiplin pada masyarakat. Kurang sadarnya masyarakat dalam hukum berlalu lintas dapat dilihat dalam perilaku seperti semakin meningkatnya pelanggaran lalu lintas oleh para pengendara kendaraan bermotor (Sadono, 2016: 62).

Perilaku ketidakdisiplinan masyarakat dalam berlalu lintas seperti mengendarai kendaraan melebihi batas kecepatan yang ditentukan, menerobos lampu lalu lintas, melewati marka pembatas jalan, tidak melengkapi alat keselamatan seperti halnya tidak menggunakan helm, spion, lampu-lampu kendaraan, ketidaklengkapan suratsurat kendaraan bermotor, tidak taat membayar pajak, hingga menggunakan kendaraan tidak laik pakai masih terus terjadi. Permasalahan tersebut sampai saat ini selalu dihadapi oleh para penegak hukum di mana hal itu sudah dianggap biasa dan menjadi kebiasaan masyarakat (Sadono, 2016: 62).

Emile Durkheim (Hendratno, 2009; Merton, 1967, dalam Sadono, 2016: 63) menggambarkan kondisi ini dengan istilah anomie, yakni berpudarnya pegangan pada kaidah-kaidah yang ada menimbulkan keadaan yang tidak stabil dan keadaan tanpa kaidah. Sebagaimana diketahui, perilaku menyimpang (deviant behavior) dapat terjadi apabila manusia mempunyai kecenderungan untuk lebih mementingkan suatu nilai sosial budaya daripada kaidah-kaidah yang ada untuk mencapai cita-cita atau kepentingan (Sadono, 2016: 63).

Terkait dengan permasalahan itulah maka pengabdian kepada masyarakat berupa penyuluhan mengenai tertib lalu lintas oleh Satuan Lalu Lintas (Satlantas) Polres Klaten ini dilaksanakan. Penyuluhan ini diselenggarakan pada Rabu, 26 Agustus 2020 bertempat di Balai Desa Taji, Klaten. Peserta yang mengikuti kegiatan ini berjumlah sekitar 50-an orang terutama dari kalangan remaja dengan materi utama mengenai tertib berlalu lintas di jalan raya. Para remaja sendiri merupakan bagian penting dari masyarakat karena mereka merupakan generasi muda yang memiliki potensi besar untuk menyebarkan ide dan gagasan kebaikan apabila

Teknologi Informasi dan Komunikasi 10 
dapat dibina dengan baik (Santrock, 2010; Alkhajar, 2014).

\section{METODE}

Dalam kegiatan pengabdian kepada masyarakat ini, pemateri menggunakan empat metode utama penyampaian materi yakni presentasi video, ceramah, diskusi dan praktik di lapangan. Metode presentasi video yakni dengan menampilkan video animasi iklan layanan masyarakat mengenai pentingnya mematuhi tata tertib lalu lintas. Video ini dibuat secara khusus oleh tim Group Riset Kajian dan Komunikasi Terapan D3 Komunikasi Terapan Sekolah Vokasi UNS. Kemudian, metode ceramah yakni dengan presentasi materi tertib berlalu lintas oleh para anggota Satlantas Polres Klaten.

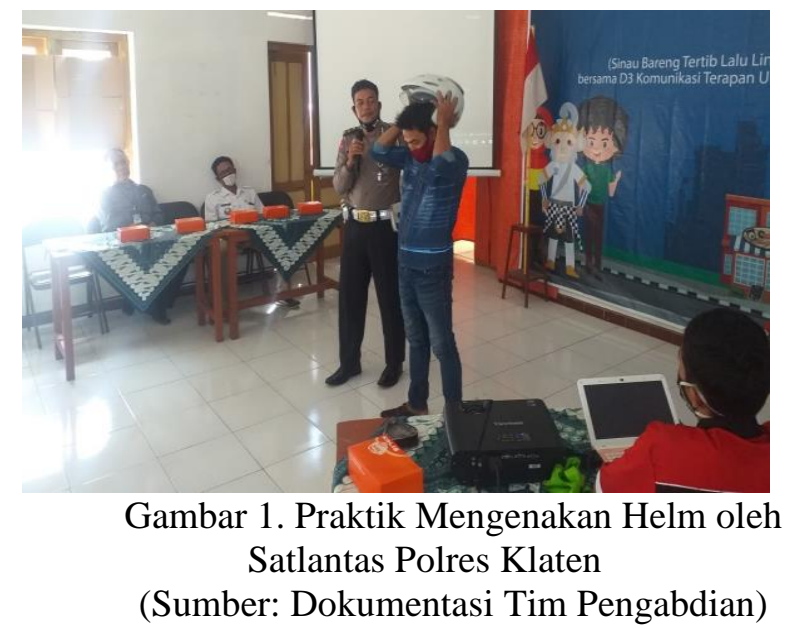

Selanjutnya, metode diskusi digunakan oleh pemateri untuk berdiskusi dengan para peserta mengenai materi yang disampaikan melalui sesi tanya jawab. Melalui metode ini para peserta diharapkan dapat semakin memahami materi yang dipaparkan. Di sisi lain, metode diskusi digunakan agar suasana kegiatan menjadi hidup karena adanya umpan balik dari peserta. Sementara itu, metode praktik di lapangan dilaksanakan dengan mempraktikkan secara langsung bagaimana cara memakai helm dan cara berkendara yang baik dan benar. Praktik langsung ini dimaksudkan agar peserta memperoleh gambaran materi secara lebih riil dan jelas tentang materi yang disampaikan.

Kegiatan pengabdian kepada masyarakat ini pun dilaksanakan dengan mengaplikasikan protokol kesehatan mengingat kondisi pandemi COVID-19. Sebagaimana diketahui, penyakit ini bukanlah perkara remeh sehingga semua pihak harus dapat beradaptasi dan berdamai dengan cara terbaik karena kesehatan merupakan hal yang sangat penting (Alkhajar \& Wijaya, 2020: vi; Wijaya \& Alkhajar, 2020: 229).

\section{HASIL DAN PEMBAHASAN}

\section{Urgensi Tertib Berlalu Lintas}

Urgensi tertib berlalu lintas ini dimaknai sebagai nilai penting yang harus benar-benar diketahui, dipahami dan dihayati oleh setiap masyarakat terutama oleh para pengguna jalan akan sangat pentingnya berlalu lintas yang baik dan benar. Tujuannya adalah terwujudnya kondisi berlalu lintas yang aman dan lancar bagi seluruh pengguna jalan serta terwujudnya budaya tertib lalu lintas bagi seluruh masyarakat. Tanpa mengetahui, memahami dan menghayati urgensi itu, maka halhal yang menjadi potensi pelanggaran lalu lintas kemungkinan besar bisa terjadi.

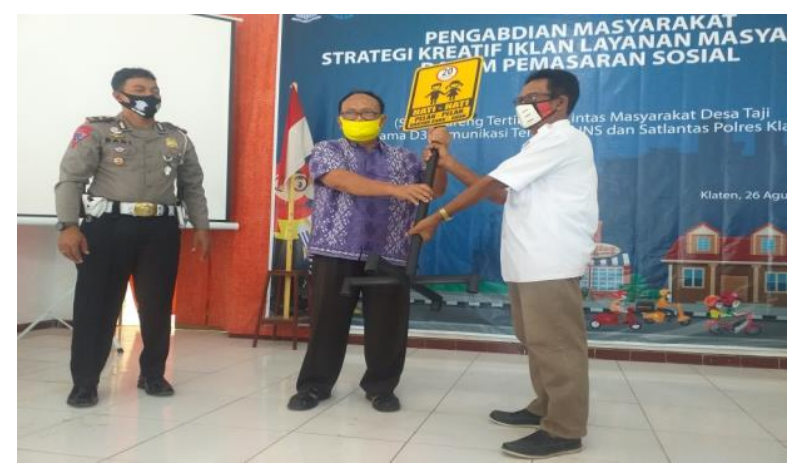

Gambar 2. Contoh Rambu Lalu Lintas (Sumber: Dokumentasi Tim Pengabdian)

Bukan hanya melanggar aturan hukum yang berlaku, namun kondisi tersebut juga bisa membahayakan keselamatan diri dan pengguna jalan yang lain. Akibat yang fatal adalah terjadinya kecelakaan di antara para pengguna jalan baik pengendara roda dua maupun roda empat yang bahkan bisa mengarah ke pejalan kaki atau masyarakat di sekitar lokasi kejadian. Efek dari kecelakaan itu bisa berbuntut proses hukum, cedera ringan, sedang dan berat bahkan hingga meninggal dunia. Sudah banyak kejadian menunjukkan hal itu sehingga masyarakat semestinya bisa berhati-hati dalam berkendara.

Teknologi Informasi dan Komunikasi 
Beberapa hal yang harus dipenuhi pengguna jalan yang berkendara antara lain: Pertama, kelengkapan surat-surat resmi berkendara seperti surat izin mengemudi (SIM), surat tanda nomor kendaraan (STNK), kartu identitas diri seperti KTP atau sejenisnya. Kelengkapan suratsurat ini penting karena menunjukkan bahwa pengguna kendaraan secara formal yuridis dianggap telah memenuhi syarat-syarat yang ditentukan regulasi, seperti telah lulus tes mengemudi, kondisi kendaraan yang digunakan benar-benar sesuai dengan surat yang berlaku, identitas pengguna kendaraan benar-benar asli dan sebagainya. Jika tidak membawa atau tidak memiliki surat-surat ini, pengendara kendaraan dianggap belum memenuhi

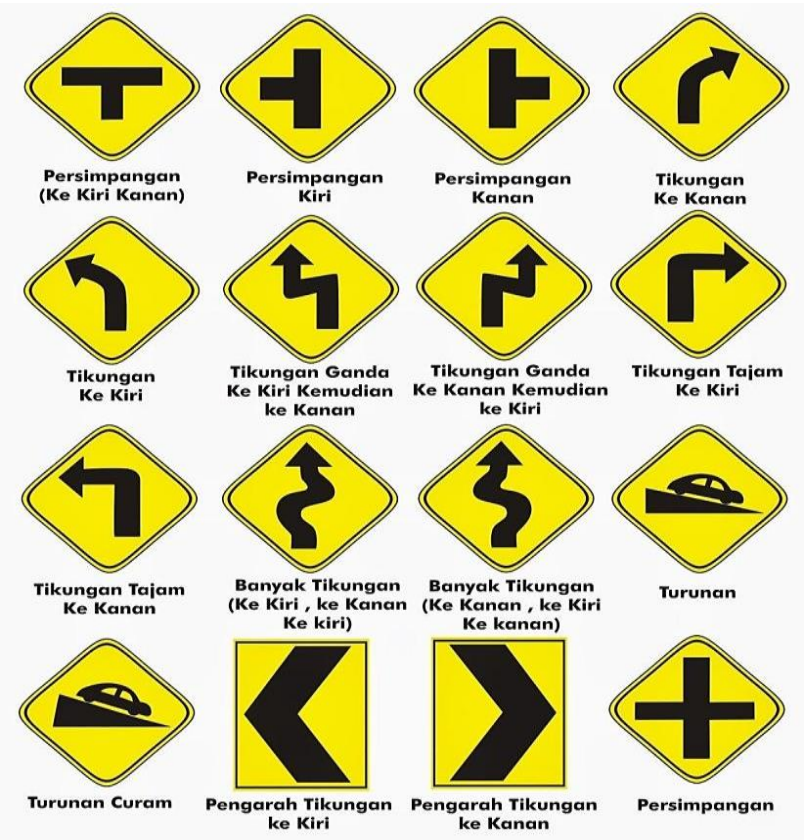

syarat untuk berkendara khususnya di jalan raya dan berpotensi melanggar peraturan.

Gambar 3. Contoh Rambu Peringatan

(Sumber: HSR Wheel, 2020)

Kedua, kelengkapan kendaraan. Dalam hal ini terkait dengan kondisi fisik dari kendaraan yang dipakai pengendara baik roda dua atau roda empat. Beberapa perlengkapan penting dari kendaraan yakni rem aktif, lampu depan belakang aktif, spion lengkap, bel aktif, sein aktif, helm dan sabuk pengaman bagi pengendara roda empat serta tentu saja mesin kendaraan dalam kondisi baik. Bahkan, jaket dengan warna cerah juga sangat penting sebagai penanda bagi pengendara jalan lain khususnya di malam hari. Beberapa onderdil fisik tersebut sangat penting dalam mendukung kelancaran dan keamanan berkendara. Bisa dibayangkan bagaimana jika rem kendaraan tidak aktif atau tidak berfungsi sedang pengendara dalam kecepatan tinggi. Maka potensi terjadinya kecelakaan sangat besar yang mana hal tersebut dapat membahayakan keselamatan diri pengendara sendiri, pengendara lain, pengguna jalan lain bahkan masyarakat.

Ketiga, mengenali, memahami dan menghayati rambu-rambu lalu lintas yang terpasang. Rambu lalu lintas adalah salah satu alat perlengkapan jalan dalam bentuk tertentu yang memuat lambang, huruf, angka, kalimat dan/atau perpaduan di antaranya, yang digunakan untuk memberikan peringatan, larangan, perintah dan petunjuk bagi pemakai jalan. Rambu lalu lintas dibuat untuk menciptakan kelancaran, keteraturan dan keselamatan dalam berkendara. Marka jalan dan rambu-rambu merupakan objek untuk menyampaikan informasi baik itu peringatan, larangan, petunjuk dan perintah.

Rambu lalu lintas dibagi menjadi empat golongan yaitu rambu peringatan, rambu larangan, rambu petunjuk dan rambu perintah. (1) Rambu Peringatan, menunjukkan kemungkinan adanya bahaya di jalan yang akan dilalui. Rambu ini berbentuk "wajik atau bujur sangkar" berwarna dasar kuning dengan lambang atau tulisan berwarna hitam (Departemen Perhubungan, 2005). (2) Rambu Larangan, menunjukkan perbuatan yang dilarang dilakukan oleh pemakai jalan. Rambu ini dengan warna dasar putih/merah dan lambang atau tulisan berwarna hitam dan merah (Departemen Perhubungan, 2005). 


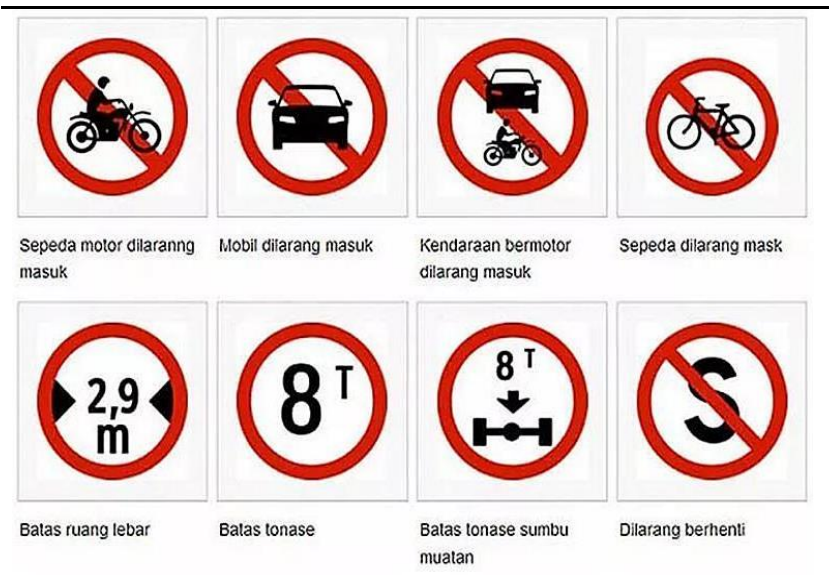

Gambar 4. Contoh Rambu Larangan

(Sumber: HSR Wheel, 2020)

(3) Rambu Petunjuk, menyatakan petunjuk mengenai jurusan jalan situasi, kota, fasilitas dan lain-lain bagi pemakai jalan. Warna dasar rambu ada warna hijau, biru dan coklat (Departemen Perhubungan, 2005).
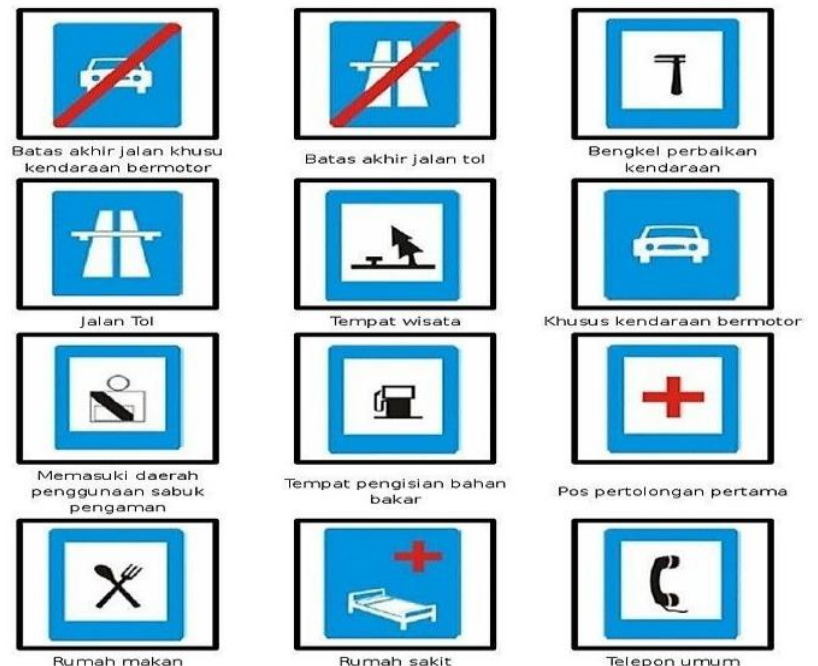

Pos pertolongan pertama

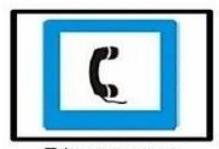

Telepon umum
Gambar 4. Contoh Rambu Petunjuk

(Sumber: HSR Wheel, 2020)

(4) Rambu Perintah, menyatakan perintah yang wajib dilakukan oleh pemakai jalan. Rambu perintah berbentuk bundar berwarna biru dengan lambang atau tulisan berwarna putih serta merah untuk garis serong sebagai batas akhir perintah (Departemen Perhubungan, 2005).
Pengendara baik itu roda dua maupun roda empat hendaknya mampu mengetahui, mengenali dan menghayati keberadaan dan fungsi ramburambu lalu lintas yang terpasang di jalan. Pelanggaran atas rambu-rambu lalu lintas yang ada berpotensi melanggar hukum dan rentan juga menimbulkan kecelakaan di jalan baik kecelakaan tunggal atau non-tunggal.

Misalnya pada lampu lalu lintas, masingmasing warna memberikan petunjuk yang berbeda kepada para pengguna jalan. Merah berarti berhenti. Tunggu di belakang garis berhenti warna putih melintang pada jalan yang memakai lampu isyarat tersebut. Kuning berarti berhenti pada garis tanda berhenti. Pengendara hanya boleh jalan melintasi suatu garis berhenti kalau pengendara sudah terlalu dekat. Hijau berarti boleh jalan terus atau boleh membelok ke kiri atau ke kanan (Departemen

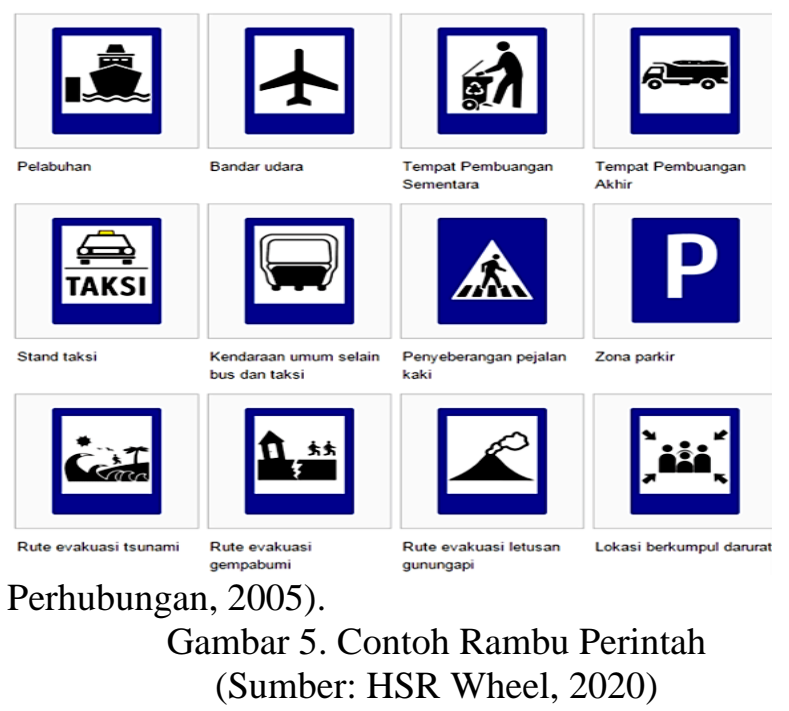

Pengetahuan dan pemahaman mengenai alat pemberi isyarat lalu lintas atau lampu lalu lintas ini haruslah dimiliki oleh para pengendara. Apa jadinya jika ada pengendara yang dirinya terus saja melaju di perempatan jalan raya padahal pada lampu lalu lintas yang terpasang sedang berwarna merah. Pelanggaran tata tertib lalu lintas sudah pasti terjadi di sini. Namun, hal yang lebih mengerikan adalah potensi besar terjadinya kecelakaan lalu lintas yang semestinya dapat dihindari. Sudah banyak sekali contoh kecelakaaan lalu lintas yang terjadi dan berakibat fatal karena pengendara melanggar lampur lalu lintas yang ada. 


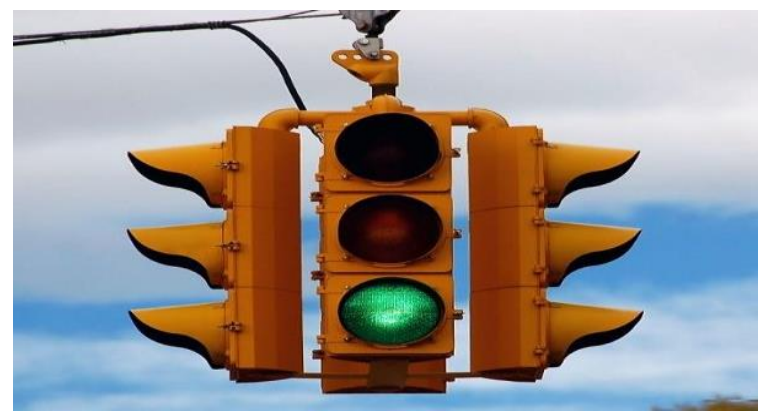

Gambar 6. Contoh Rambu Lampu Lalu Lintas (Sumber: Seruni.id, 2019)

Termasuk di sini adalah para pengguna jalan harus memperhatikan marka jalan. Garis utuh tunggal merupakan larangan bagi kendaraan melintasi garis tersebut. Garis tunggal terputusputus merupakan garis yang membagi arus lalu lintas dan dapat dilintasi oleh kendaraan untuk menyalip. Garis ganda utuh putih bermakna pengendara harus mengambil sebelah kiri jalur rangkap. Pengendara tidak boleh melintasi garis tersebut untuk melewati kendaraan maupun membelok. Garis ganda putih dengan garis utuh dekat pengendara bermakna pengendara harus ambil sebelah kiri garis utuh ini dan jangan melintasinya untuk melewati. Garis ganda putih dengan garis terputus-putus lebih dekat dengan pengendara bermakna pengendara boleh melintasi garis ini untuk melewati bila jalan di depan aman (Departemen Perhubungan, 2005).
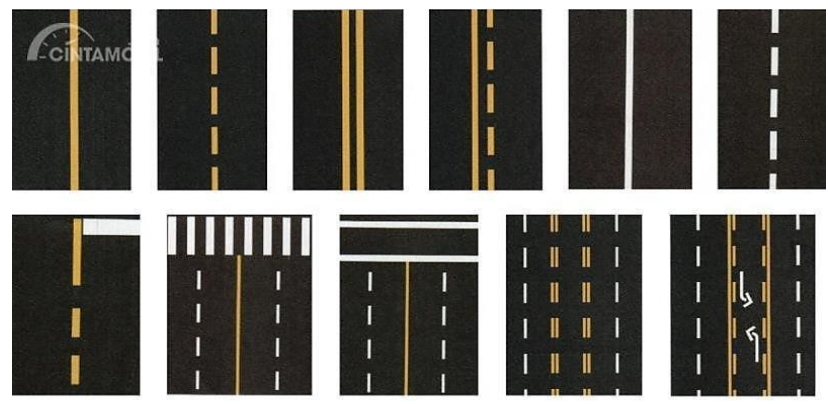

Gambar 7. Contoh Rambu Marka Jalan (Sumber: Nugraha, 2019)

Keempat, etika di jalan raya. Etika bisa dimaknai sebagai hal-hal yang terkait sopan santun, layak atau tidak layak bahkan benar atau tidak benar. Di jalan raya, pengguna jalan khususnya para pengendara semestinya memperhatikan dan menerapkan etika berkendara yang baik. Misalnya, tidak meludah atau membuang sampah dari kendaraan dengan sembarangan, tidak mengerem mendadak, tidak merokok saat berkendara, tidak mabuk saat kondisi berkendara, tidak mengakses telepon genggam saat berkendara, tidak berkendara dengan kecepatan tinggi atau sangat tinggi (mengebut), tidak berjejer saat berkendara terutama sepeda motor dan lain-lain.

Etika di jalan raya ini sangat penting untuk dipraktikkan agar tercipta suasana berlalu lintas yang kondusif, aman dan nyaman. Tentu menjadi sangat tidak nyaman manakala ada pengendara lain yang misalnya membuang sampah dari dalam mobil ketika berkendara di jalan raya.

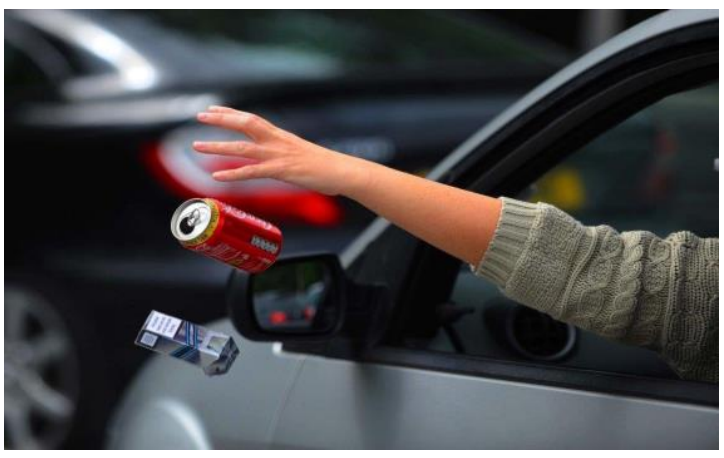

Gambar 8. Contoh Pelanggaran Etika Lalu Lintas (Sumber: Sag, 2019).

\section{KESIMPULAN}

Secara keseluruhan kegiatan pengabdian kepada masyarakat berupa penyuluhan tentang tertib berlalu lintas kepada kalangan remaja ini berjalan dengan baik dan lancar. Para peserta pun telah mendapatkan pendidikan tertib berlalu lintas yang sangat penting di antaranya berkenaan dengan urgensi tertib berlalu lintas, kelengkapan berkendara, pemahaman tentang rambu-rambu lalu lintas, dan etika lalu lintas.

Urgensi tertib lalu lintas sangat penting karena berkaitan dengan pemahaman, penghayatan dan kepatuhan terhadap tata tertib lalu lintas. Kelengkapan berkendara berhubungan dengan kelengkapan surat-surat resmi berkendara, kondisi fisik kendaraan dan kondisi fisik pengendara. Pemahaman rambu-rambu lalu lintas terkait pengenalan dan pendalaman tentang jenis-jenis

Teknologi Informasi dan Komunikasi 
rambu-rambu lalu lintas di jalan. Sementara itu, etika berlalu lintas berkaitan dengan sopan santun tatkala berkendara di jalan. Dampak dari kegiatan ini adalah meningkatnya wawasan dan kesadaran para peserta untuk berhati-hati dan tertib berlalu lintas saat berkendara di jalan raya. Hal ini tercermin dari sebagian peserta yang sebelumnya belum memiliki SIM kemudian mendaftarkan diri dalam pengurusan SIM ke Satlantas Polres Klaten. Di sisi lain, para peserta juga aktif terlibat dalam upaya mensosialisasikan dan mendiseminasikan budaya tertib berlalu lintas kepada rekan sebayanya maupun anggota masyarakat yang lain.

\section{REFERENSI}

Alkhajar, E. N. S. (2007). Hiperealitas dalam Kehidupan Nyata. Kompas, 31 Desember.

Alkhajar, E. N. S. (2014). Media, Masyarakat dan Realitas Sosial. Surakarta: Sebelas Maret University Press.

Alkhajar, E. N. S., \& Wijaya, S. H. B. (Eds.). (2020). Dinamika Komunikasi dalam Pandemi COVID-19. Yogyakarta: KBM Indonesia.

Departemen Perhubungan. (2005). Buku Petunjuk Tata Cara Berlalu Lintas (Highway Code) di Indonesia. Jakarta: Direktorat Jenderal Perhubungan Darat Departemen Perhubungan.

HSR Wheel. (2020). 4 Rambu Lalu Lintas yang Sering Ditemukan, Wajib Tahu!. Diakses September 12, 2020, dari https://hsrwheel.com/blog/4-rambu-lalu-lintasyang-sering-ditemukan-wajib-tahu/.

Nugraha, R. F. (2019, October 18). Mengenal Arti Garis Marka di Jalan Raya, Wajib Anda Ketahui!. Diakses September 12, 2020, dari https://cintamobil.com/pengemudian/mengenal-artigaris-marka-di-jalan-raya-wajib-anda-ketahuiaid6531.

Prasetya, R. K. (2016). Diversi dan Pelaku Kecelakaan Lalu Lintas. DiH Jurnal Ilmu Hukum, 12(24), 93-101.

Rahawarin, F. (2016). Implementasi Undang-Undang RI Nomor 22 Tahun 2009 Tentang Lalu Lintas Dan Angkutan Jalan (Studi Di Kota Ambon). Tahkim, 12(2), 125-141.
Ramadhan, A. (2020, December 19). Polri Sebut Jumlah Kecelakaan Lalu Lintas Meningkat pada 2019. Diakses September 12, 2020, dari https://nasional.kompas.com/read/2019/12/28/1035 5741/polri-sebut-jumlah-kecelakaan-lalu-lintasmeningkat-pada-2019.

Sadono, S. (2016). Budaya Tertib BerlaluLintas "Kajian Fenomenologis Atas Masyarakat Pengendara Sepeda Motor Di Kota Bandung." Channel, 4(1), 61-79.

Sag, F. (2019, July 11). Awas, Membuang Sampah di Jalan Tol Bisa Kena Denda Rp 1 Juta. Diakses September 12, 2020, dari https://cintamobil.com/pengemudian/awas-

membuang-sampah-di-jalan-tol-bisa-kena-denda-rp1-juta-aid5392.

Santrock, J. W. (2010). Adolescence. New York: McGraw-Hill.

Sarwono, S. W. (2011). Psikologi Remaja. Jakarta: PT. Raja Grafindo Persada.

Seruni.id. (2019). Bagaimana Asal Mula Lampu Lalu Lintas? Ini Dia Sejarahnya. Diakses September 12, 2020, dari https://seruni.id/lampulalu-lintas/.

Undang-Undang RI Nomor 22 Tahun 2009 tentang Lalu Lintas dan Angkutan Jalan (LLAJ).

Wijaya, S. H. B., \& Alkhajar, E. N. S. (2020). Memotret Pandemi: Hoaks Covid-19 dan Paradoks Kemanusiaan. In F. Junaedi (Ed.), Krisis Komunikasi dalam Pandemi Covid-19 (pp. 229233). Yogyakarta: Buku Litera. 